\title{
Is the Złoczew lignite deposit geologically suitable for the first underground gasification installation in Poland?
}

\author{
Paweł Urbański*, Marek Widera² \\ ${ }^{1}$ Polish Geological Institute - National Research Institute, 4 Rakowiecka Street, 00-975 Warszawa, Poland \\ ${ }^{2}$ Institute of Geology, Adam Mickiewicz University, 12 Krygowski Street, 61-680 Poznań, Poland \\ "corresponding author, e-mail: purb@pgi.gov.pl
}

\begin{abstract}
The present study focuses on alternative methods of exploiting lignite in comparison to conventional opencast mining and combustion in power plants for the generation of electricity. In Poland, opencast lignite pits cover large areas, creating social and environmental conflicts. In order to stabilise the production level of electricity and reduce the negative effects of opencast mining, alternative ways of exploiting lignite are suggested, one of these being underground gasification in situ. The Złoczew lignite deposit, which will most likely be exploited in the near future, provides an opportunity to discuss the unconventional method of underground coal gasification (UCG). On the basis of technological and geological criteria that have been established to determine the suitability of Polish lignite for underground gasification, resources to be used this way have been estimated. Through gasification, over 15 million tonnes of lignite can be utilised, which is about 2.5 per cent of resources of the Złoczew deposit intended for opencast mining. With this in mind, we suggest to take action by starting a pilot installation, to be followed by a commercial one for underground gasification after completion of superficial mining. Naturally, any future application of this method will be preceded by assessment of geological conditions at the Złoczew opencast pit.
\end{abstract}

Key words: tectonic graben, lignite seams, UCG criteria, clean energy, Miocene, central Poland

\section{Introduction}

Currently, coal (hard coal and lignite) accounts for $\sim 38$ per cent of the world's production of electricity (WCA, 2018). As far as Poland is concerned, hard coal and lignite together cover $\sim 85$ per cent, while the latter is used to generate $\sim 30-35$ per cent (> 50-55 TWh per year) of domestic electricity (Tajduś et al., 2014; Widera et al., 2016; Kasztelewicz et al., 2018; Pietraszewski, 2018). Annual lignite mining in Poland has stabilised over the last few years in the range of 58-65 million tonnes. These data show that Poland ranks amongst the most important lignite producers in the world and takes second place in the European Union after the world leader, Germany (EURACOAL, 2018; WCA, 2018).

The majority of lignite deposits in Poland are found the central-western part of the country (Fig. 1). In total, there are over 70 lignite deposits, only seven of which are exploited in five mines, namely Adamów ( $\sim 0.5$ million tonnes), Bełchatów ( $>44$ million tonnes), Konin ( $>8$ million tonnes), Sienia- 


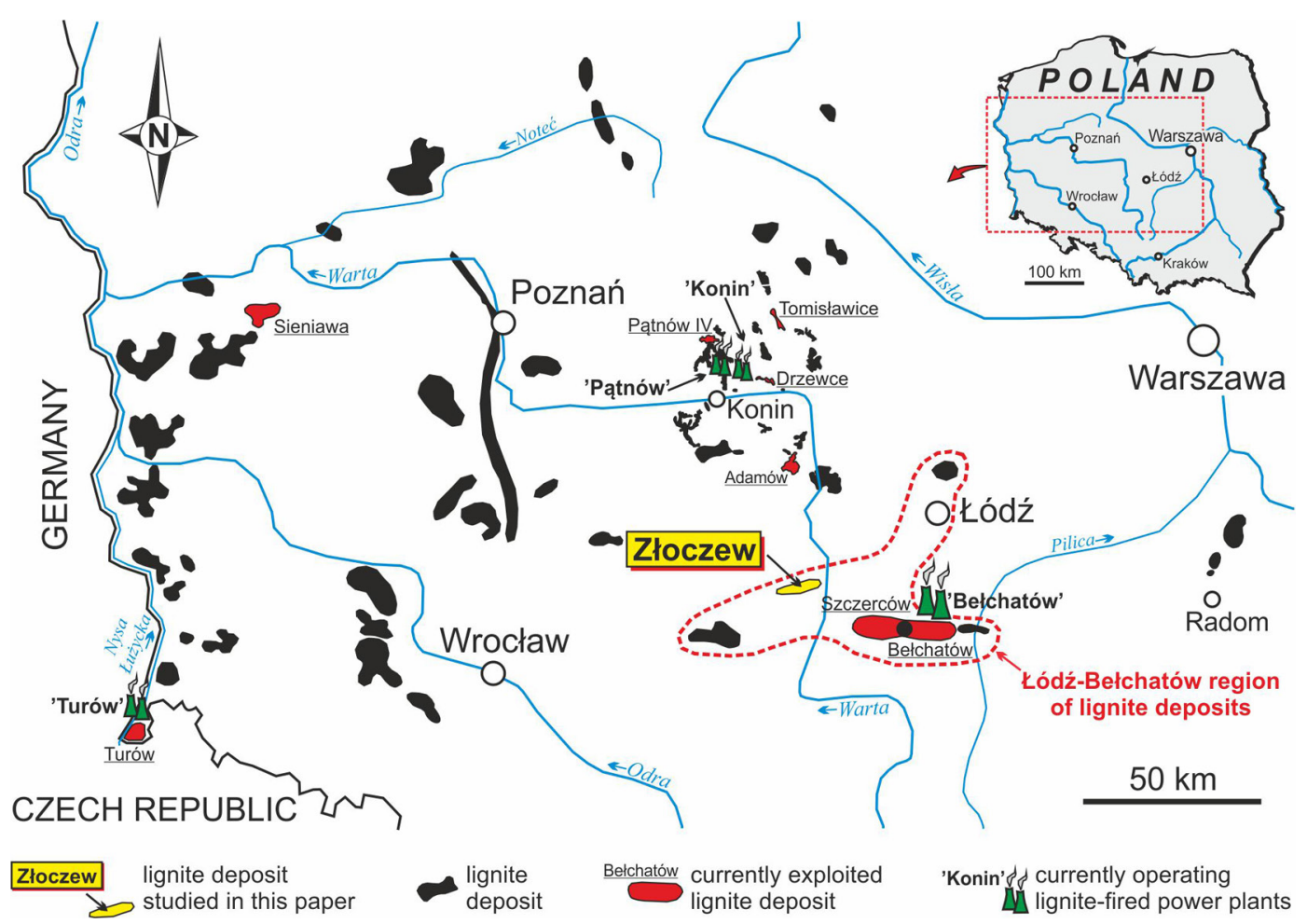

Fig. 1. Location of the Złoczew lignite deposits on the background of major lignite deposits in Poland (modified after Ciuk \& Piwocki, 1990; Kasiński, 2010; Widera, 2016; Widera et al., 2016). Note the location of the Złoczew deposit studied in relation to other deposits of the Łódź-Bełchatów region of lignite deposits and the Bełchatów power plant

wa ( $\sim 0.1$ million tonnes) and Turów ( $<7$ million tonnes). Obviously, the Bełchatów Lignite Mine and power plant are in first place, accounting for $>70$ per cent of the total lignite extraction and generation of electricity in Poland. The Złoczew lignite deposit, with reserves to the amount of $\sim 612$ million tonnes, belongs to the Łódź-Bełchatów region of lignite deposits. The relatively short distance $(\sim 50 \mathrm{~km})$ from the Bełchatów power plant means that this deposit is currently considered as prospective for this lignite-fired power plant after the successive closure of the Bełchatów and Szczerców opencast pits (Fig. 1; Kasiński \& Piwocki, 2002; Kasiński et al., 2006; Kasiński, 2010; Kasztelewicz, 2014; Widera et al., 2016). Methods other than conventional (opencast) ways of mining lignite in Poland have already receive a lot of attention in the literature (e.g., Stańczyk et al., 2011; Kasiński et al., 2012; Kasztelewicz et al., 2013; Bielowicz \& Kasiński, 2014; Matl et al., 2014; Bielowicz, 2016; Urbański \& Saternus, 2017; Bucha et al., 2018; Detman et al., 2018; Szafranek-Nakonieczna et al., 2018).

These unconventional methods can be grouped into those that take place in situ (i.e., within the deposit) or ex situ (i.e., at the surface) and those in which organic matter is burnt or biochemical (e.g., bacteria or fungi) processes are used. In other words, subterranean gasification of coal essentially includes two technologies, that is, UCG and biogasification. In the former, synthetic gas (syngas) is produced, while in the latter, biogenic gas (biogas) is created (Iciek et al., 2009; Ritter et al., 2015). From amongst unconventional methods, special attention to UCG is drawn in the present paper. Similar to biogas, syngas (obtained in underground conditions) can be utilised for the generation of electricity or as feedstock in the production of liquid fuels and other chemical substances. Moreover, the majority of contaminants in the UCG process remain underground and do not pollute surface waters or the air. We refer anyone interested in the history, concepts and technologies of UCG, to the following publications: Bednarczyk (2007), Klimenko (2009), Kapusta et al. (2010), Hajdo et al. (2012), Kasiński et al. (2012), Self et al. (2012), Bhutto et al. (2013), Bielowicz \& Kasiński (2014), Dubiński \& Turek (2016), Mao (2016), Memon et al. (2016) and Sobczyk et al. (2017) (and references therein).

In Poland, lignite is exploited exclusively in opencast pits (Fig. 1). This may create social and environmental conflicts. The former involve resettlement of the rural population living in close proximity or within the area of future lignite excavations (e.g., Kasiński et al., 2006; Uberman \& Naworyta, 2012; Badera \& Kocon, 2014), while the latter are linked to the dewatering of deposits, opencast min- 
ing technology, transport from opencast pits to the power plants and the burning of lignite. The most important conflicts include changes in geological and hydrogeological conditions, noise pollution and dust formation, creation of overburden dumps and air pollution from e.g., $\mathrm{CO}_{2}$ emissions (see Kapusta \& Stańczyk, 2011; Kapusta et al., 2010; Tajduś et al., 2014; Urbański \& Widera, 2016; Przybyłek \& Dąbrowski, 2017). To avoid the negative effects of surface mining, the UCG method, which is the best known of all unconventional methods, being used in pilot installations around the world, can be applied to some lignite deposits in Poland, including the Złoczew deposit.

The main goals of the present study are: 1) to characterise the geology of the area of the Złoczew lignite deposit; 2) to propose alternative methods of lignite extraction for selected areas (lignite fields) of this deposit; 3) to discuss technological and geological criteria for assessing the suitability of lignite seams for UCG; and 4) to propose a ranking of lignite fields from the Złoczew deposit for planning the installation of both pilot and commercial operations.

\section{Geological setting}

The Złoczew lignite deposit in central Poland, 50 $\mathrm{km}$ west of Bełchatów and $\sim 70 \mathrm{~km}$ southwest of Łódź (Fig. 1), is found in a relatively deep (up to $350 \mathrm{~m}$ ), fault-bounded tectonic depression which is referred to as the Złoczew Graben (e.g., Deczkowski \& Gajewska, 1977; Gotowała \& Hałuszczak, 2002). This tectonic structure is $\sim 15 \mathrm{~km}$ long and $1-1.5 \mathrm{~km}$ wide and shows a WSW-ENE trend. The graben bedrock consists predominantly of Mid-Jurassic limestones, marls and mudstones and Upper Jurassic limestones. Locally, carbonate rocks of Late Cretaceous age are also found (Deczkowski \& Gajewska, 1977; Sawicki, 2010). Taking the genetic classification of Polish lignite deposits into consideration, the Złoczew deposit belongs to the tectonic type (i.e., those located in a fault-bounded graben) and to the carbonate-karst subtype (Ciuk, 1968; Kasiński \& Piwocki, 2002; Widera, 2016). In fact, the karstification process played only a symbolic role in the formation of the thick lignite seams that create the Złoczew deposit; however, its effects are well documented in the form of cavities in the top of the Mesozoic carbonate bedrock (Kasiński, 2015).

The graben is filled with Cenozoic sedimentary rocks, including lignites (Fig. 2), with a thin (up to a few metres), discontinuous layer of weathered Mesozoic rocks (clay and mud) at the base. In fact,

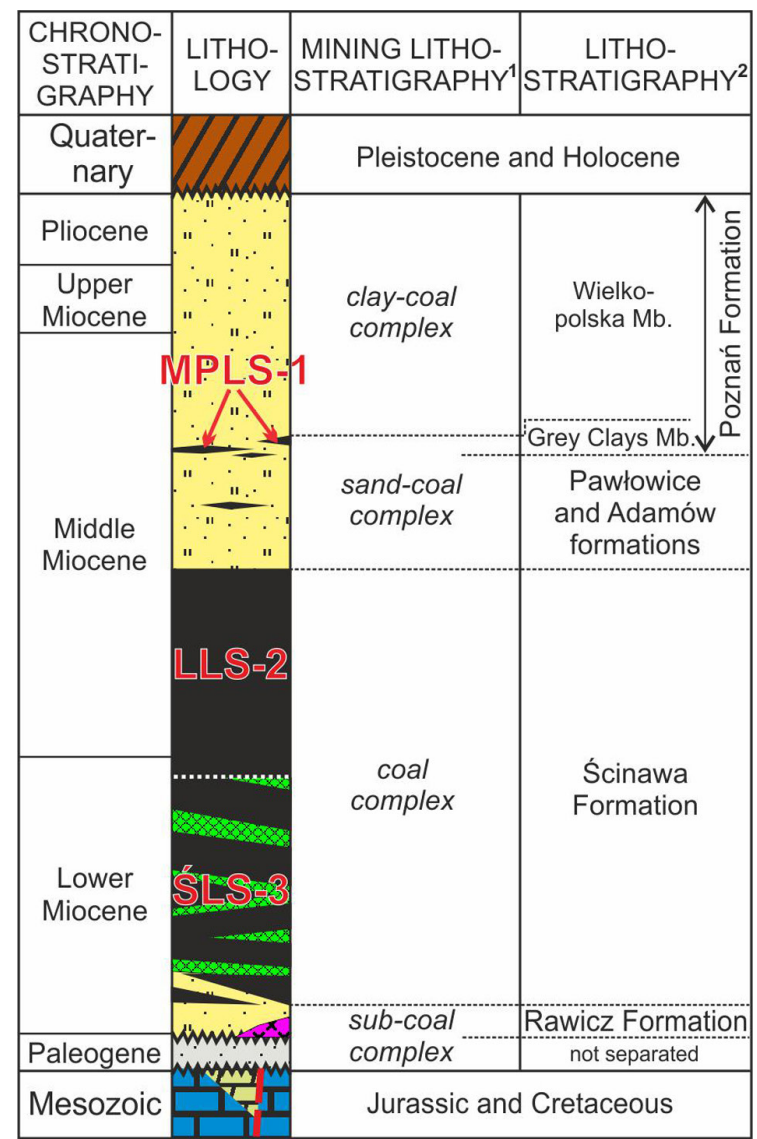

4 Jurassic and Cretaceous carbonates (limestone, marlstone, mudstone)

$\begin{array}{lll}\therefore & \text { Paleogene weathered rocks } \\ \because & \text { (clay, mud) }\end{array}$

\section{" . . . Neogene siliciclastics (sand, silt, clay)}

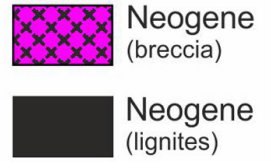

main un-
conformity

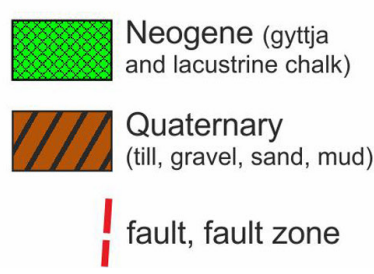

Fig. 2. Simplified stratigraphical sketch of the Cenozoic succession in the area of the Złoczew lignite deposit (modified after Sawicki, 2010; Widera, 2016; Urbański \& Saternus, 2017)

${ }^{1}$ - mining lithostratigraphy the same as in the Bełchatów lignite deposit (after Czarnecki et al., 1992; Gotowała \& Hałuszczak, 2002); ${ }^{2}$ - Neogene lithostratigraphy for the territory of the Polish Lowlands (after Piwocki \& Ziembińska-Tworzydło, 1997; Widera, 2007); position of lignite seams on a chronostratigraphical background (after Piwocki \& Ziembińska-Tworzydło, 1997; Kasiński et al., 2010; Kasiński \& Słodkowska, 2016); ŚLS-3 - $3^{\text {rd }}$ Ścinawa lignite seam; LLS-2 - $2^{\text {nd }}$ Lusatian lignite seam; MPLS-1 $-1^{\text {st }}$ mid-Polish lignite seam; note that in some places lignite seams ŚLS-3 and LLS-2 rest directly on each other 
the pronounced evolution of the Złoczew Graben commenced at the turn of the Paleogene and Neogene, as is demonstrated by the presence of significantly thicker deposits of this age in the axial zone of the graben. At that time, Neogene sands (sporadically with breccia), assigned to the Rawicz Formation, were deposited. Together with the Paleogene weathered rocks, they make up the so-called subcoal complex (Fig. 2). This is covered by the coal complex, which contains the $3^{\text {rd }}$ Ścinawa and the $2^{\text {nd }}$ Lusatian lignite seams. The lignite benches are often interbedded by gyttja and lacustrine chalk. These lignites jointly create one thick seam (16.1-114.4 m, averaging $46.2 \mathrm{~m}$ ), which is referred to as the main lignite seam (Sawicki, 2010; Urbański \& Saternus, 2017). The coal complex, with non-organic interbeds, corresponds to the Ścinawa Formation in the remaining area of the Polish Lowlands (Piwocki \& Ziembińska-Tworzydło, 1997; Widera, 2007). Above this formation follow sand-coal and clay-coal complexes, with relatively rare and thin lenses of lignite belonging to the $1^{\text {st }}$ mid-Polish lignite seam in the top layers of former complex. These two lithological complexes constitute the Neogene overburden of the main lignite seam. They can be loosely linked with the Pawłowice, Adamów and Poznań formations (Fig. 2). The Cenozoic succession in the vicinity of the Złoczew lignite deposits is terminated by a thick (a few tens of metres) glaciogenic Quaternary cover, consisting mainly of till, gravel and sand.

\section{Data and methods}

The main source of information used in the present paper are logs of boreholes sunk to identify and document lignite resources in the Złoczew deposit. Lithological and stratigraphical data from 48 boreholes, ranging in depth from $<100 \mathrm{~m}$ (on the graben flanks) to $>350 \mathrm{~m}$ (in the deepest, axial zone of the graben), have been used to construct four cross sections (Fig. 3). One of these runs through the axial zone of the tectonic structure and the lignite deposit, while the remaining three are perpendicular to the first and to the strike of the graben and the Złoczew lignite deposit (Fig. 4). They are positioned in such a way as to show the hypsometric position and overburden geology of lignite fields suggested for UCG (Figs. 3, 4). These boreholes, included in the newest geological documentation of the Złoczew lignite deposit and other older material, are part of the National Geological Archive of the Polish Geological Institute - National Research Institute (Warsaw).

Currently, the basic criteria for determining the usefulness of lignite seams in Poland for opencast mining are a minimum thickness of 3 metres and an overburden ratio less than 12 . However, some lignite deposits, and the prevailing part of the lignite-bearing areas in Poland for that matter, do not meet these criteria. Therefore, during the last decade, many scientists (e.g., Nowak \& Barańska-Bus-

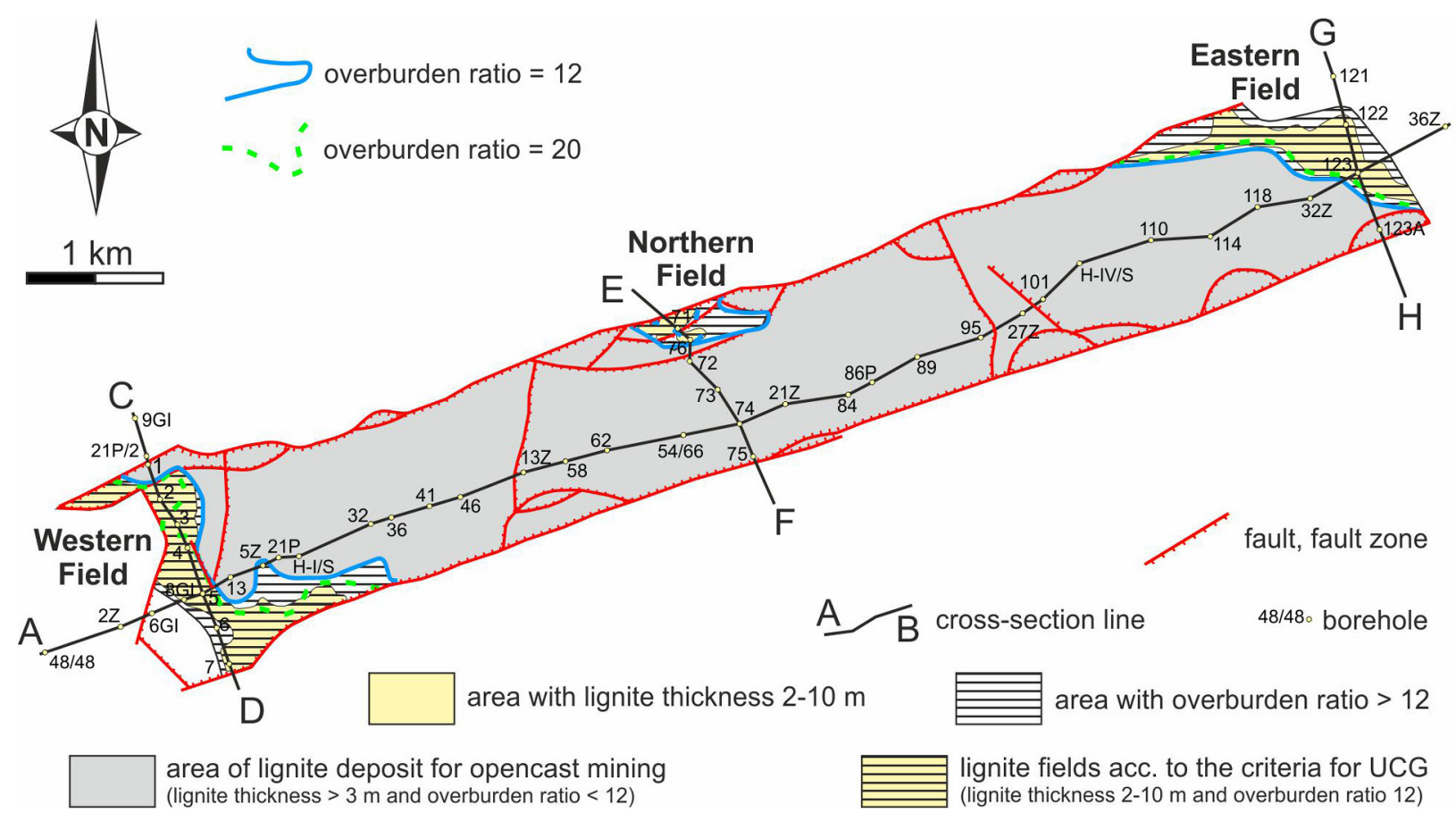

Fig. 3. Outline of the Złoczew deposit with fields for possible underground gasification of lignite (modified after Urbański \& Saternus, 2017). For cross sections see Figure 4 
lik, 2011; Hajdo et al., 2012; Kasiński et al., 2012; Bielowicz \& Kasiński, 2014; Matl et al., 2014 and Urbański \& Saternus, 2017, and references therein) have attempted to come up with criteria for lignite deposits in Poland that cannot be exploited conventionally, but may be suitable for UCG (Table 1). Due to the complex geological conditions, they are very general and loose in nature in comparison with requirements for such deposits in other countries. Therefore, the criteria proposed here, which include mainly geological, technological and environmental ones, still are only theoretical, meaning that they have not yet been tested. In this respect, some portions of the Złoczew deposit provide an opportunity for applying and discussing existing criteria for UCG of lignite deposits in Poland (Table 1).

Table 1. Criteria for underground gasification of Polish lignites used in the present paper (modified after Nowak \& Barańska-Buslik, 2011; Hajdo et al., 2012; Kasiński et al., 2012; Bielowicz \& Kasiński, 2014; Matl et al., 2014). For location and geological position of fields W, N and E see Figures 3 and 4, respectively

\begin{tabular}{|c|c|c|}
\hline No. & Criterion & Range of variability \\
\hline 1 & $\begin{array}{l}\text { physicochemical parameters: } \\
\text { - calorific value } \\
\text { - volatile matter } \\
\text { - ash content } \\
\text { - natural moisture } \\
\text { - sulfur content }\end{array}$ & $\begin{array}{l}\text { minimum amount not specified (suggested }>6.5 \mathrm{MJ} / \mathrm{kg})^{1} \\
<50 \%^{1} \\
<20 \% \text {; optionally } 25 \%^{1} \\
<55 \%^{1} \\
<4.0 \%^{1}\end{array}$ \\
\hline 2 & $\begin{array}{l}\text { deposit thickness: } \\
\text { - minimal } \\
\text { - maximum }\end{array}$ & $\begin{array}{l}2 \mathrm{~m} \text {; up to } 4 \mathrm{~m} \text { (optimal) }{ }^{1} \\
10 \mathrm{~m} \\
4 \mathrm{~m} \text { - optimal, dependent on hydraulic insulation, overall conservation } \\
\text { and the conservation of the boreholes (controlling overburden col- } \\
\text { lapse) }\end{array}$ \\
\hline 3 & $\begin{array}{l}\text { depth: } \\
\text { - minimal }\end{array}$ & $\begin{array}{l}>150 \mathrm{~m}^{1} \text { - below erosion washouts; in other cases the depth may be } \\
\text { lower }\end{array}$ \\
\hline 4 & $\begin{array}{l}\text { deposit type: } \\
\text { - single-seam deposit } \\
\text { - multi-seam deposit }\end{array}$ & $\begin{array}{l}\text { preferred } \\
\text { possible when using advanced technology (e.g., using backfill), the } \\
\text { distance between seams }>20 \mathrm{~m}^{2}\end{array}$ \\
\hline 5 & overburden ratio & $>12$ (10) top of the deposit at a depth of up to $350 \mathrm{~m}^{2}$ \\
\hline 6 & inclination of the deposit & horizontal or slightly inclined ${ }^{1}$ \\
\hline 7 & $\begin{array}{l}\text { thermal insulation of the surrounding } \\
\text { rocks }\end{array}$ & $\begin{array}{l}\text { roof rocks are clays and silts of very low permeability }\left(\mathrm{k} \leq 9 \times 10^{-8} \mathrm{~m} / \mathrm{s}\right) \\
\text { with a thickness of } \geq 10-20 \mathrm{~m} ; 2.8 \text { of deposit thickness }{ }^{2}\end{array}$ \\
\hline 8 & $\begin{array}{l}\text { the hydrogeological conditions: } \\
\text { - position in relation to aquifer } \\
\text { - volume of water flow to the seam }\end{array}$ & $\begin{array}{l}\text { below the usable aquifers and outside the major groundwater reser- } \\
\text { voirs, the minimum distance is } 40 \mathrm{~m} \\
\text { below } 2 \mathrm{~m}^{3} \text { /ton of lignite without additional draining }{ }^{2}\end{array}$ \\
\hline 9 & tectonics & $\begin{array}{l}\text { no cracks and faults, no significant tectonic disturbances within the } \\
\text { mining fields }{ }^{2}\end{array}$ \\
\hline 10 & the porosity of the surrounding rocks & $\begin{array}{l}\text { roof rocks and the floor rocks should have lower gas permeability than } \\
\text { lignite seam, while the thickness of poorly permeable rocks surround- } \\
\text { ing the seam should be } 1-2 \mathrm{~m} \text { or } 2-4 \mathrm{~m} \text { for } 2 \mathrm{~m} \text { and } 3-10 \mathrm{~m} \text { of seam } \\
\text { thickness, respectively }{ }^{2}\end{array}$ \\
\hline 11 & the amount of reserves & $\begin{array}{l}\text { reserves required for pilot plant are around } 0.075-0.45 \text { million tons, } \\
\text { while commercial project will need a minimum of } 3.5 \text { million tons }{ }^{2}\end{array}$ \\
\hline 12 & filtration properties of the rock & $\begin{array}{l}\text { the ratio of porosity of lignite seam to that of surrounding rocks should } \\
\text { not be less than } \mathrm{mD} 18: 20^{2}\end{array}$ \\
\hline & & Depending on location \\
\hline 13 & $\begin{array}{l}\text { the area required for underground } \\
\text { lignite gasification plant }\end{array}$ & $\begin{array}{l}\text { minimal area for the pilot plant is } 50-100 \mathrm{ha}\left(0.5-1 \mathrm{~km}^{2}\right) \text {, while for the } \\
\text { commercial installation it is over } 100 \mathrm{ha}\left(1 \mathrm{~km}^{2}\right)^{2}\end{array}$ \\
\hline 14 & safety conditions & $\begin{array}{l}\text { minimum distance from: residential areas }(1-3 \mathrm{~km}) \text {, rivers and lakes } \\
(1-3 \mathrm{~km}), \text { protected areas }(5 \mathrm{~km}) \text {, currently exploited mines/mining } \\
\text { areas }(5 \mathrm{~km}) \text {, abandoned mines/workings }(3 \mathrm{~km}) \text {, transmission lines } \\
\text { and railways }(1-3 \mathrm{~km})^{2}\end{array}$ \\
\hline
\end{tabular}

${ }^{1}$ criteria acc. to Bielowicz \& Kasiński (2014); ${ }^{2}$ criteria acc. to Nowak \& Barańska-Buslik (2011). 


\section{Results}

\subsection{Geology of lignite fields suitable for UCG}

Most of the Złoczew lignite deposit is suitable for opencast mining (Fig. 3), because the lignite seam is $>3 \mathrm{~m}$ thick (46.2 $\mathrm{m}$ on average) and the overburden ratio less than 12 (4.5 on average). Other geological and mining parameters are also acceptable, as are technological and chemical ones. The situation is different in three relatively small portions of this deposit for which the basic criteria for opencast mining are not fully met: the Western Field (W Field), Northern Field (N Field) and Eastern Field (E Field) (Fig. 3). However, these three fields do meet most of the criteria for UCG (compare Table 1).

In the present paper, the geological description of these Złoczew field for application of UCG will focus on both lignite and overburden. The three fields (W, N and E) are located in the most westerly, northerly and easterly parts of the lignite deposit and tectonic structure (Figs. 3, 4). Lignite in these places is relatively thin (from $<10 \mathrm{~m}$ to $<2 \mathrm{~m}$ ) and found in a high hypsometric position $(\sim 0 \mathrm{~m}$ a.s.l. on average) when compared to the axial zone of the graben. Thus, the overburden of the lignite seam has an average thickness that exceeds 160-170 metres, predominantly consisting of loose siliciclastics of Neogene (mainly sand) and Quaternary (mainly sand and gravel) age. In addition, there are continuous layers of cohesive sediment, such as Neogene clays and Quaternary (Pleistocene) tills (compare Fig. 4 and Table 1), which is a fundamental condition as far as the UCG process is concerned. However, it must be clearly stated here that thermal insulation of the surrounding rocks is generally good. This confirms the thickness of cohesive deposits in the overburden (mainly clay and muddy clay), which in the majority of boreholes exceeds 20 metres, and on average is 44.5 metres (Fig. 4).

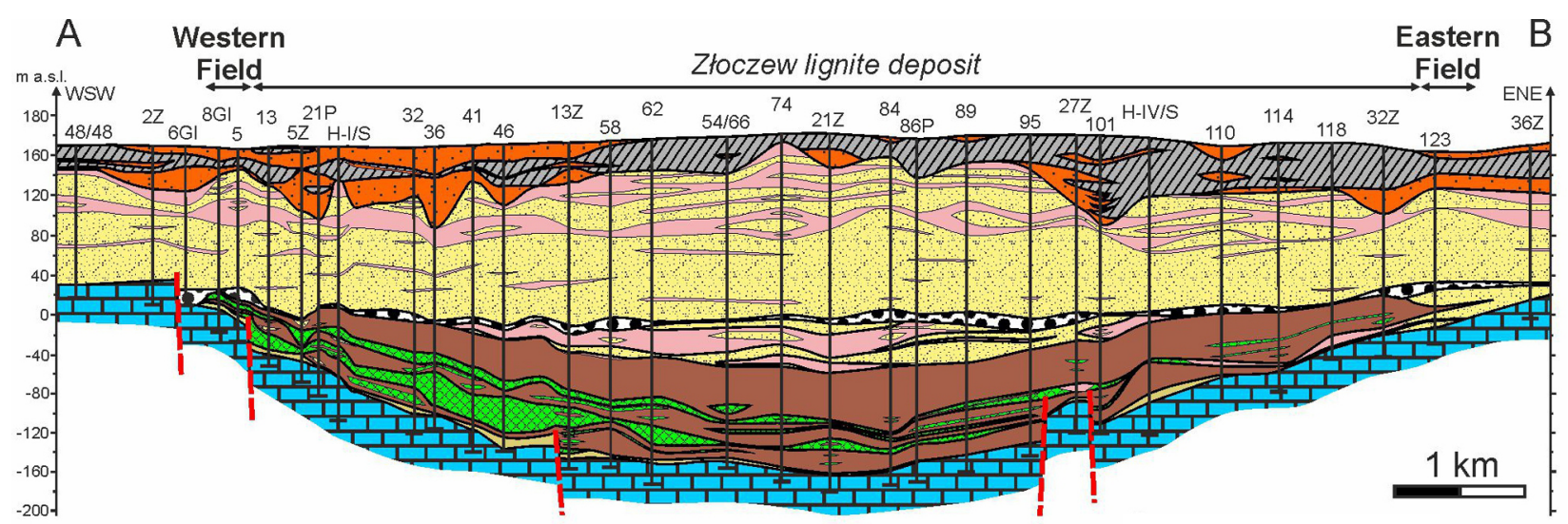

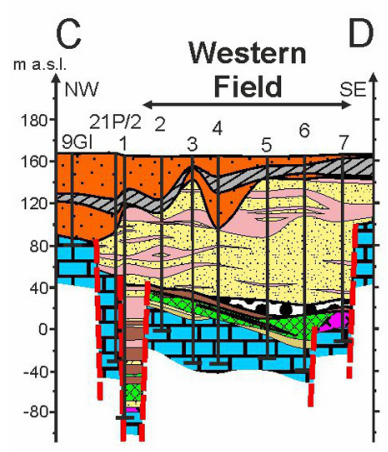

Neogene:

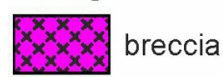

gyttia and lacustrine chalk
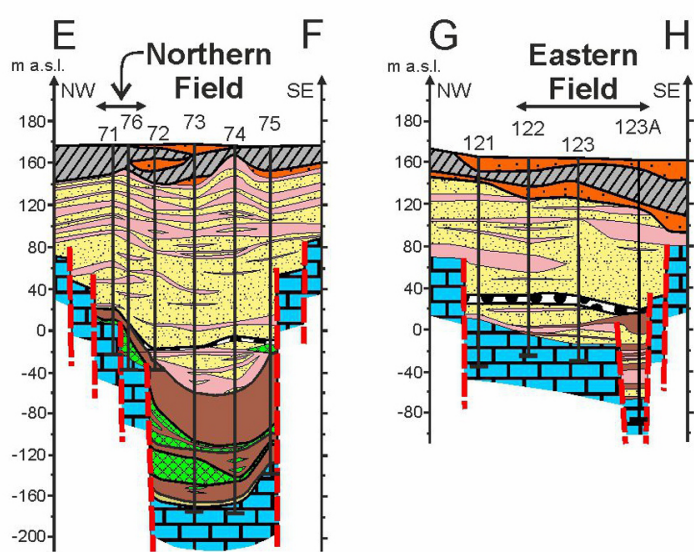

Quaternary:
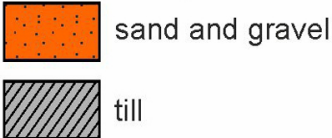

\section{Paleogene:}

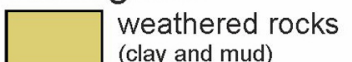

Mesozoic:

Jurassic and Cretaceous (limestone, marlstone, mudstone)

Fig. 4. Geological cross sections through the Złoczew lignite deposit. Longitudinal cross section A-B with W and E fields; cross section C-D with W Field; cross section E-F with N Field; cross section G-H with E Field; for location of cross sections see Figure 3 
The Złoczew lignite deposit is situated beyond major groundwater reservoirs. There are three aquifers: Quaternary, Paleogene-Neogene and Upper Jurassic. Each of these is characterised by diverse hydrogeological parameters and lithology. Thus, the Upper Jurassic limestones have a very high permeability, the filtration coefficient being in the range of 15.5-76.4 m/day. Despite the significant inflow of reservoir waters, these will come mainly (as is the case also in the nearby Bełchatów lignite deposit) from karst crevices in carbonate sedimentary rocks on the slopes of the opencast pit. Therefore, they will be removed as a result of mine drainage.

In view of the fact the Złoczew deposit fills the tectonic graben, all dislocations, including faults, must be taken into account when planning the installation for UCG. Obviously, the faults below the lignite seam are of little importance in the gasification process; those with open fissures could greatly limit or even preclude the use of the lignite deposit for UCG purposes. Fortunately, faults in the overburden of the Złoczew lignite deposit are rare, and because they are mostly tightened and clogged, intensive migration of water and gases is prevented.

\subsection{Extent and resources of lignite fields for UCG plants}

The three fragments of the Złoczew lignite deposit (Figs. 3, 4) selected for UCG mentioned above cannot be exploited in opencast pits because they do not meet the criteria. However, they do partially meet criteria for UCG (Table 1). Of these three fields, only the W Field meets the conditions $(>0.5$ $\mathrm{km}^{2}$ ) for a pilot plant with a total areal extent of $0.818 \mathrm{~km}^{2}$ and a lignite thickness of $2-10 \mathrm{~m}$ over an area of $0.589 \mathrm{~km}^{2}$, which is more than the required $0.5 \mathrm{~km}^{2}$ (Table 2; Fig. 5). The remaining $\mathrm{E}$ and $\mathrm{N}$ fields, considered separately, have an areal extent of $<0.5 \mathrm{~km}^{2}$. Thus, they do not meet the basic criterion for UCG (i.e., area $>0.5 \mathrm{~km}^{2}$ ); however, their status may change when the W Field is being exploited, in which case the $\mathrm{E}$ and $\mathrm{N}$ fields can be operated together with the $W$ Field in various configurations, that is, fields $\mathrm{W}$ and $\mathrm{E}$ or fields $\mathrm{W}, \mathrm{E}$ and N. In such situations, the criteria for both pilot and commercial plants will be met (compare Tables 1, 2 and Fig. 5).

Taking into account the lignite reserves in these fields, UCG looks promising (Table 3; Fig. 6). The required reserves for a pilot plant range from 0.075 to 0.45 million tonnes, while reserves for commercial plants should exceed 3.5 million tonnes (Table 1). All three fields meet the criteria for a pilot plant, because their reserves are between 0.56 and 4.28 million tonnes. In the case of a commercial plant, the criteria for UCG are met in the W and E fields. An exception is the N Field where total reserves are slightly smaller (2.92 million tonnes) than recommended (compare Tables 1, 3 and Fig. 6). Howev$\mathrm{er}$, in case of combined gasification of the $\mathrm{W}$ and $\mathrm{E}$ fields or the $\mathrm{W}, \mathrm{E}$ and $\mathrm{N}$ fields, lignite reserves will be sufficient for both pilot and commercial plants (Table 3; Fig. 6).

Based on the recommended 2-10 m thickness of lignite, most reserves are found in the $\mathrm{W}$ and $\mathrm{E}$ fields, containing 52.6 and 70.3 per cent of their total reserves, respectively. This is in marked contrast to the N Field which includes only 19.3 per cent lignite in layers with a thickness of 2-10 m (Table 3; Fig. 6). It is worth adding here that in the case of the $\mathrm{W}$ and $E$ fields, the largest portion of lignites analysed (40.2-48.4 per cent of reserves) reaches a thickness of 5-10 m. This thickness interval is not investigated in detail in the present paper, but it clearly shows that the recommended 4 metres of lignite thickness, optimal for UCG (see Table 1), is out of this range. Therefore, assuming a preferred theoretical range

Table 2. Field areas in relation to the area required for underground lignite gasification plant (modified after Urbański \& Saternus, 2017). For location and geological position of fields W, N and E see Figures 3 and 4, respectively

\begin{tabular}{lccccccccccc}
\hline \multicolumn{1}{c}{ Area } & \multicolumn{2}{c}{ Field W } & \multicolumn{2}{c}{ Field E } & \multicolumn{2}{c}{ Field N } & \multicolumn{3}{c}{ Fields W+E } & \multicolumn{2}{c}{ Fields W+E+N } \\
\cline { 2 - 11 } & $\mathrm{km}^{2}$ & $\%$ & $\mathrm{~km}^{2}$ & $\%$ & $\mathrm{~km}^{2}$ & $\%$ & $\mathrm{~km}^{2}$ & $\%$ & $\mathrm{~km}^{2}$ & $\%$ \\
\hline $\begin{array}{l}\text { acc. to condition for UCG: } \\
\text { overburden ratio > 12 } \\
\text { thickness 2-10 m }\end{array}$ & $\mathbf{0 . 5 8 9}$ & $\mathbf{7 2 . 0}$ & 0.422 & 84.5 & 0.059 & 31.4 & $\mathbf{1 . 0 1 1}$ & $\mathbf{7 6 . 8}$ & $\mathbf{1 . 0 7 0}$ & $\mathbf{7 1 . 1}$ \\
$\begin{array}{l}\text { overburden ratio > 12 } \\
\text { thickness 10-20 m }\end{array}$ & 0.216 & 26.4 & 0.077 & 15.5 & 0.116 & 61.9 & 0.293 & 22.2 & 0.409 & 27.2 \\
$\begin{array}{l}\text { overburden ratio > 12 } \\
\text { thickness > 20 m }\end{array}$ & 0.013 & 1.6 & 0.000 & 0.0 & 0.013 & 6.7 & 0.013 & 1.0 & 0.025 & 1.7 \\
total & $\mathbf{0 . 8 1 8}$ & $\mathbf{1 0 0 . 0}$ & $\mathbf{0 . 4 9 9}$ & $\mathbf{1 0 0 . 0}$ & 0.188 & 100.0 & $\mathbf{1 . 3 1 7}$ & $\mathbf{1 0 0 . 0}$ & $\mathbf{1 . 5 0 4}$ & $\mathbf{1 0 0 . 0}$
\end{tabular}

recommended reserves for the pilot plant: $0.5-1.0 \mathrm{~km}^{2}$

recommended reserves for the commercial installation: $>1.0 \mathrm{~km}^{2}$. 
of 3-5 m $(4 \pm 1 \mathrm{~m})$, the lignite reserves contained therein would be 15.8 per cent (W Field) and 10.7 per cent (E Field) of the reserves included in beds with a thickness of 2-20 m (Urbański \& Saternus, 2017).

Summing up the issues that concern these fields and the amount of their reserves, there are significant differences depending on criteria applied for both pilot and commercial UCG plants. In terms of areal extent, only the $\mathrm{W}$ Field qualifies for a pilot plant (Table 2; Fig. 5). The W Field is also suitable for a commercial plant on account of reserves con-

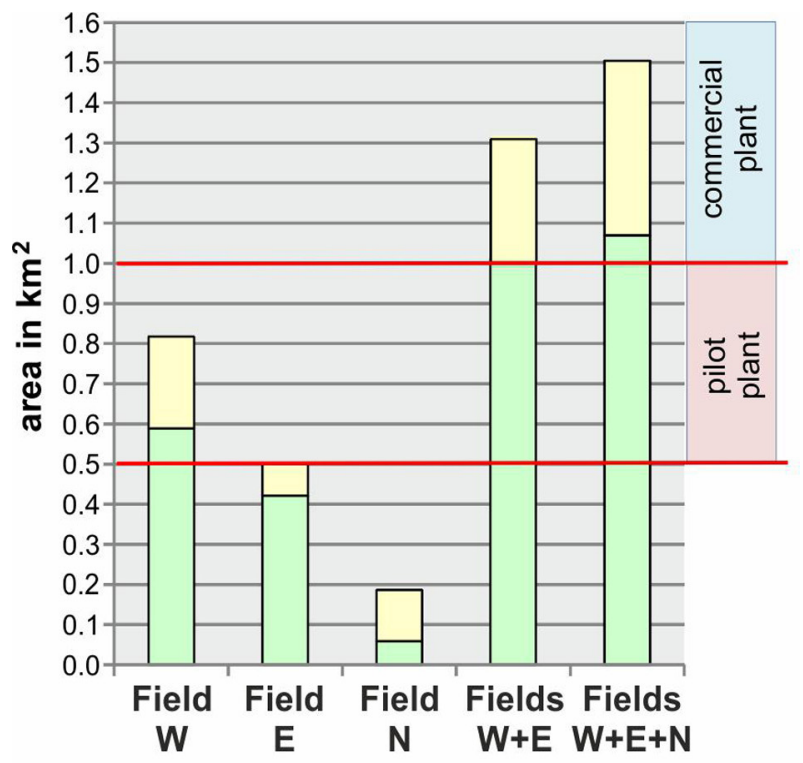

$\square$ area with:

overburden ratio $>12$, lignite thickness $>10 \mathrm{~m}$ area that meets criteria for UCG:

overburden ratio $>12$, lignite thickness 2-10 m

Fig. 5. Diagram showing the size of the lignite fields analysed depending on criteria used (modified after Urbański \& Saternus, 2017). For detailed data see Table 2 tained in layers with a thickness of 2-10 metres. For layers with a thickness of 2-20 metres, reserves amount to 7.58 million tonnes. In contrast, the $\mathrm{E}$ Field may be useful for a commercial plant only when using a wider range of lignite thickness, for example, 2-20 metres and reserves of 3.93 million tonnes. The $\mathrm{N}$ Field does not meet the criteria for UCG in either variant, that is, 2-10 or 2-20 metres with reserves of 2.59 million tonnes (Table 3 and Fig. 6). However, it is close to fulfilling the criteria and could be conditionally used for UCG (Urbański \& Saternus, 2017).

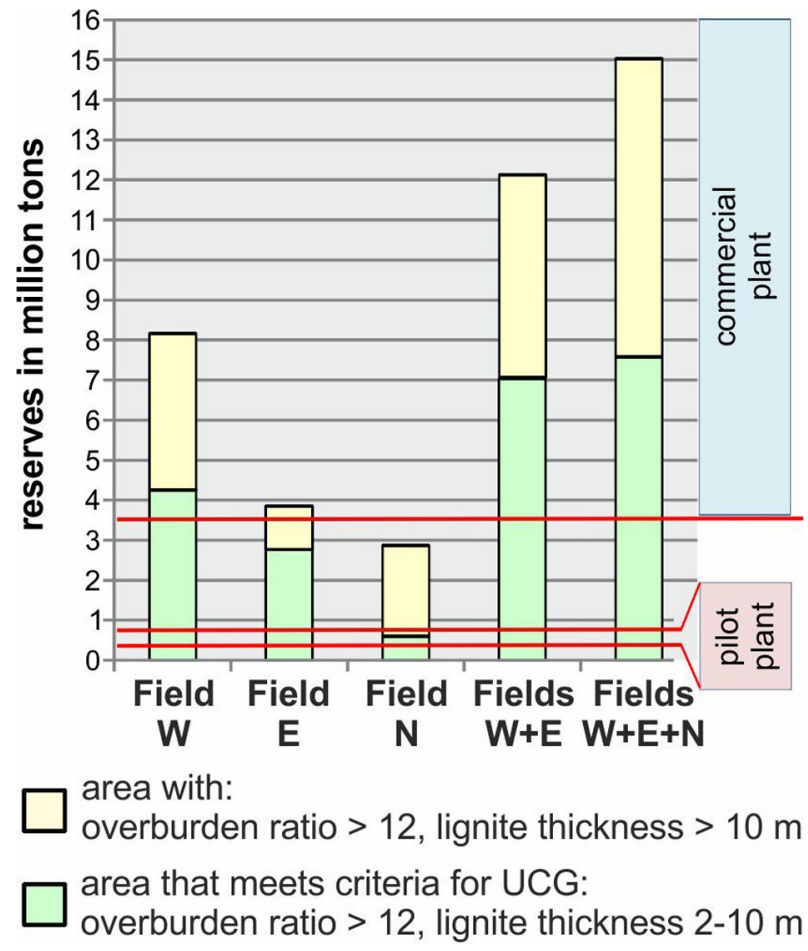

Fig. 6. Diagram showing resources of the lignite fields analysed depending on criteria used (modified after Urbański \& Saternus, 2017). For detailed data see Table 3

Table 3. Field reserves in relation to the area required for underground lignite gasification plant (modified after Urbański \& Saternus, 2017). For location and geological position of fields W, N and E see Figures 3 and 4, respectively

\begin{tabular}{|c|c|c|c|c|c|c|c|c|c|c|}
\hline \multirow[b]{2}{*}{ Area } & \multicolumn{2}{|c|}{ Field W } & \multicolumn{2}{|c|}{ Field E } & \multicolumn{2}{|c|}{ Field N } & \multicolumn{2}{|c|}{ Fields $W+E$} & \multicolumn{2}{|c|}{ Fields $\mathrm{W}+\mathrm{E}+\mathrm{N}$} \\
\hline & $\begin{array}{c}\text { million } \\
\text { tons }\end{array}$ & $\%$ & $\begin{array}{c}\text { million } \\
\text { tons }\end{array}$ & $\%$ & $\begin{array}{l}\text { million } \\
\text { tons }\end{array}$ & $\%$ & $\begin{array}{l}\text { million } \\
\text { tons }\end{array}$ & $\%$ & $\begin{array}{c}\text { million } \\
\text { tons }\end{array}$ & $\%$ \\
\hline $\begin{array}{l}\text { acc. to condition for UCG: } \\
\text { overburden ratio }>12 \\
\text { thickness } 2-10 \mathrm{~m}\end{array}$ & 4.28 & 52.6 & 2.77 & 70.3 & 0.56 & 19.3 & 7.06 & 58.4 & 7.62 & 50.7 \\
\hline $\begin{array}{l}\text { overburden ratio > } 12 \\
\text { thickness } 10-20 \mathrm{~m}\end{array}$ & 3.50 & 42.9 & 1.16 & 29.5 & 2.03 & 69.4 & 4.66 & 38.5 & 6.69 & 44.6 \\
\hline $\begin{array}{l}\text { overburden ratio }>12 \\
\text { thickness }>20 \mathrm{~m}\end{array}$ & 0.36 & 4.5 & 0.01 & 0.2 & 0.33 & 11.3 & 0.37 & 3.1 & 0.70 & 4.7 \\
\hline total & 8.14 & 100.0 & 3.94 & 100.0 & 2.92 & 100.0 & 12.09 & 100.0 & 15.01 & 100.0 \\
\hline
\end{tabular}

recommended reserves for the pilot plant: $0.075-0.45$ million tons recommended reserves for the commercial installation: $>3.5$ million tons. 


\section{Discussion}

The calculations presented above show that the restrictive application of theoretical criteria for UCG, included in Table 1, may leave significant amounts of unused lignite in this deposit. Hence, existing criteria have been tested in the present paper for selected fields of the Złoczew lignite deposit. Whether the fields qualify for UCG depends on three lignite parameters: reserves, thickness and areal extent (Fig. 7).

It has been assumed that the average bulk density of lignite equals 1.2 tonnes $/ \mathrm{m}^{3}$. For the area of the fields selected and lignite thickness, data listed in Table 1 have been adopted. As a result, characteristic fields for the pilot plant (blue field) and for the commercial one (yellow field) have been obtained (Fig. 7). Additionally, the W, E and $\mathrm{N}$ fields studied have been ranked. In terms of reserves, the order of fields is as follows: W, E and N, with the W Field having the largest reserves. However, when the most favourable distribution of lignite thickness (in the range of 3-5 metres) is considered, the ranking becomes: E, W and N (Urbański \& Saternus, 2017, Table 4).
The lignite fields selected for UCG and opencast mining are directly adjacent to each other (compare Figs. 3 and 4). Obviously, regardless of technological limitations, the coeval exploitation of the Złoczew deposit using both UCG and opencast methods should not be taken into account, because part of the lignite seam would remain unused. Hence, it is recommended that lignite beds with a thickness in excess of 10 metres be gasified, which is not in accordance with the current criteria for UCG (Table 1). That is why calculations of reserves for lignite thicknesses in the range of 10-20 metres are also presented here (compare Tables 2, 3 and Figs. $5,6)$.

Here, parameters of some of the world's coal seams that have been subject to UCG must be discussed briefly. Ortho-lignite that is only slightly more coalified than (ortho-)lignite from the Złoczew deposit, is exploited by gasification on an industrial scale in, among other places, the Tula coalfield near Moscow (Table 4). For example, average annual synthetic gas production reached 2 billion $\mathrm{Nm}^{3}$ in the Podmoskownaja 2 UCG plant (e.g., Hajdo et al., 2012). Similar volumes of syngas have been gener-

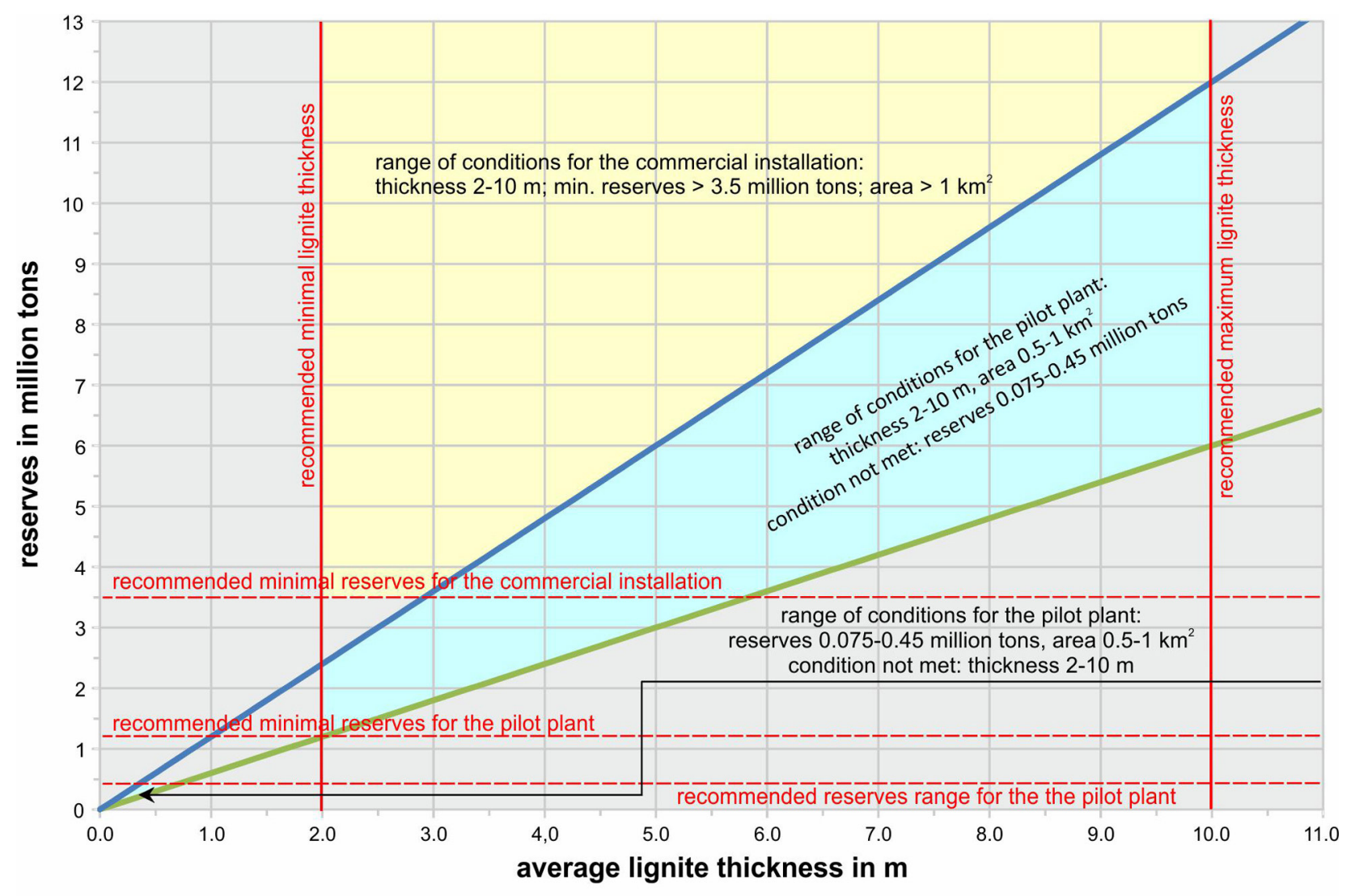

reserves for $0.5 \mathrm{~km}^{2}$ in million tons

reserves for $1.0 \mathrm{~km}^{2}$ in million tons

Fig. 7. Changing criteria of lignite suitability for UCG installations depending on thickness, reserves and size of lignite fields (modified after Urbański \& Saternus, 2017). Compare with Tables 1-3 and Figures 5-6 
Table 4. Geological, mining, chemical and technological parameters of coal seams as intended objects for UCG installations (modified after Hajdo et al., 2012; Kasiński et al., 2012)

\begin{tabular}{lcccccccc}
\hline \multirow{2}{*}{$\begin{array}{c}\text { Installation } \\
\text { (UCG plant) }\end{array}$} & Country & Coal type & Depth & $\begin{array}{c}\text { Deposit } \\
\text { thickness }\end{array}$ & $\begin{array}{c}\text { Volatile } \\
\text { matter }\end{array}$ & $\begin{array}{c}\text { Calorific } \\
\text { value }\end{array}$ & $\begin{array}{c}\text { Ash } \\
\text { content }\end{array}$ & $\begin{array}{c}\text { Natural } \\
\text { moisture }\end{array}$ \\
\cline { 5 - 10 } & & & {$[\mathrm{m}]$} & {$[\mathrm{m}]$} & {$[\%]$} & {$[\mathrm{MJ} / \mathrm{Mg}]$} & {$[\%]$} & {$[\%]$} \\
\hline Angren & Uzbekistan & meta-lignite & $40-200$ & $4.0-24.0$ & 33.0 & 15100 & 12.2 & 35 \\
Chinchilla & Australia & sub-bituminous & 140 & $8.0-10.0$ & 40.0 & 23000 & 19.3 & 10 \\
Hanna & USA & sub-bituminous & $90-120$ & 6.8 & 36.1 & 22300 & 26.3 & no data \\
Lisiczansk & Ukraine & sub-bituminous & $110-200$ & $4.0-20.0$ & $39-40$ & 22100 & $7-17$ & $12-15$ \\
Podmoskownaja 1 & Russia & ortho-lignite & $30-80$ & 2.5 & 44.5 & 11800 & 34.3 & 30 \\
Podmoskownaja 2 & Russia & ortho-lignite & 50 & $1.0-5.0$ & 44.5 & 11800 & 34.3 & 30 \\
Sinelnikowski & Russia & ortho-lignite & $30-50$ & $1.0-4.0$ & 65.5 & 8000 & 23.8 & 55 \\
Szatskaja 1 & Russia & ortho-lignite & $30-60$ & $2.6-4.0$ & 38.1 & 11100 & 26 & 30 \\
Tremendal & Spain & sub-bituminous & $530-580$ & $2.0-5.0$ & 27.5 & 18100 & 14.3 & 22.2 \\
Złoczew & Poland & ortho-lignite & $120-150$ & $2.0-10.0$ & 60.0 & 8100 & $16-33$ & 55 \\
\hline
\end{tabular}

ated from 1965 onwards by the Angren installation in Uzbekistan; however, in this case meta-lignite is utilised. Other UCG plants are found in Australia (Chinchilla), the United States (Hanna), Ukraine (Lisiczansk), Russia (Podmoskovnaya 2, Sinelnikowski and Szatskaja 1) and Spain (Tremedal). They use (or used) coal with various degrees of coalification (from ortho-lignite to sub-bituminous), as well as different parameters (Table 4).

Finally, the possibility of another unconventional method of underground gasification of lignite from the Złoczew deposit should be discussed. As noted in the introduction, UCG is currently the best known and most commonly used method globally: coal/lignite is burnt underground in an environment of air, oxygen, water and water vapour or their admixtures, at a temperature of several hundred degrees Celsius. Such high temperatures are very dangerous for surface waters, especially when lignite overburden is not sufficiently tight. This threat exists in the case of the Złoczew deposit because some poorly permeable beds (clays and tills) are relatively thin $(<10 \mathrm{~m})$ and their continuity is uncertain; however, this can be documented during opencast mining. Therefore, the use of underground biogasification, as an alternative to UCG, is considered in the present paper. Before biogasification of lignite can be used directly in the deposit, it must undergo rigorous laboratory tests (e.g., Ritter et al., 2015). It should be noted that research into biogasification of lignite in Poland has accelerated in recent years (e.g., Bucha et al., 2018; Detman et al., 2018 and Szafranek-Nakonieczna et al., 2018, and references therein).

\section{Conclusions}

The total reserves of the Złoczew lignite deposit intended for opencast mining exceed 600 million tonnes, of which $\sim 2.5$ per cent probably may be suitable for underground coal gasification (UCG). Obviously, this unconventional mining method can be used after closure of the planned Złoczew lignite opencast. Therefore, three relatively small parts (fields) of this deposit have been selected for UCG; the Western, Northern and Eastern fields.

The Złoczew deposit studied includes two relatively thick lignite seams, namely the $3^{\text {rd }}$ Ścinawa and the $2^{\text {nd }}$ Lusatian seams. High lignite quality and quite favourable geological conditions enable various means of utilisation. In addition to opencast mining, it seems that some parts of the Złoczew deposits (i.e., the three fields mentioned above) can also be subsequently gasified underground (UCG).

Within the context of a changing energy policy in the European Union, the construction of new opencasts and extraction of larger amounts of lignite in Poland appears unlikely. Thus, UCG (and potentially biogasification) may be an alternative or supplementary method of mining lignite, not only in the Złoczew deposit studied here.

The basic calculations for each lignite field (W, N and $\mathrm{E}$ ) have first been made in accordance with existing criteria for UCG. Then, similar calculations have been made according to modified criteria, thereby increasing the reserves and usability of the lignite fields analysed for both pilot and commercial plants.

Taking into account the sizeable Polish lignite reserves not suitable for opencast mining, UCG seems to be a promising way for producing domestic electricity in the future. The launch of the first UCG plant (both pilot and commercial) in the Złoczew deposit could accelerate the transformation of the Polish energy industry. As a result, both national energy security and a share of the so-called lignite-generated "clean energy" would increase significantly.

An overview of available coal seam parameters for both working and abandoned plants of UCG 
across the world does not provide a significant solution to the problem discussed in the present paper. This means that the values of the parameters are very different in the case of individual installations. In addition, most of these are associated with the use of sub-bituminous coal, and only few concern lignite utilisation. Thus, any comparison of the planned Polish UCG plant with foreign ones is fraught with difficulties and does not yield relevant data.

Finally, it must be clearly stated that it is nearly impossible to meet all criteria for UCG, listed here, in view of the geological reality of lignite deposits in Poland. Hence, a ranking of these criteria must be established in the near future, taking into consideration the problems encountered during the use of the first UCG plants. This ranking will not (and cannot) be a permanent one, but will be adapted for each individual lignite deposit.

\section{Acknowledgements}

We wish to thank two anonymous reviewers for their critical remarks and valuable suggestions that have led to considerable improvement of the original typescript. The corresponding author (PU) collected and elaborated all data, while the second author (MW) helped in describing the geology of the study area and in editorial and linguistic correction of the text.

\section{References}

Badera, J. \& Kocoń, P., 2014. Local community opinions regarding the socio-environmental aspects of lignite surface mining: Experiences from central Poland. Energy Policy 66, 507-516.

Bednarczyk, J., 2007. Rozwój technologii podziemnego zgazowania węgla i perspektywy jej przemysłowego wdrożenia [Development of underground coal gasification technology and prospects for its industrial implementation]. Górnictwo i Geoinżynieria 31, 87-104.

Bhutto, A.W., Bazmi, A.A. \& Zahedi, G., 2013. Underground coal gasification: from fundamentals to applications. Progress in Energy and Combustion Science 39, 189-214.

Bielowicz, B., 2016. The suitability of polish ortho-lignite deposits for clean coal technologies. Gospodarka Surowcami Mineralnymi-Mineral Resources Management 32 109-127.

Bielowicz, B. \& Kasiński, J.R., 2014. The possibility of underground gasification of lignite from Polish deposits. International Journal of Coal Geology 131, 304-318.

Bucha, M., Jędrysek, M.O., Kufka, D., Pleśniak, Ł., Marynowski, L., Kubiak, K. \& Błaszczyk, M., 2018. Methanogenic fermentation of lignite with car- bon-bearing additives, inferred from stable carbon and hydrogen isotopes. International Journal of Coal Geology 186, 65-79.

Ciuk, E., 1968. Types of brown coal deposits within coal-bearing formations of continental tertiary of Poland. 23 ${ }^{\text {rd }}$ Geological Congress, Prague, pp. 119-134.

Ciuk, E. \& Piwocki, M., 1990. Map of brown-coal deposits and prospect areas in Poland, scale 1:500 000. Polish Geological Institute, Warsaw.

Czarnecki, L., Frankowski, R. \& Kuszneruk, J., 1992. Syntetyczny profil litostratygraficzny utworów trzeciorzędu złoża Bełchatów [Synthetic lithostratigraphic profile of the Tertiary deposits of the Betchatów deposit]. [In:] I. Lipiarski (Ed.): Geologia formacji węglonośnych Polski [Geology of Polish coal-bearing formations]. Wydawnictwo Akademii Górniczo-Hutniczej, Kraków, pp.79-83.

Deczkowski, Z. \& Gajewska, I., 1977. The characteristics of late Cimmebian and Laramie block structures of the Fore-Sudetic Monocline. Geological Quarterly 21, 467-481.

Detman, A., Bucha, M., Simoneit, B.R.T., Mielecki, D., Piwowarczyk, C., Chojnacka, A., Błaszczyk, M.K., Jędrysek, M.O., Marynowski, L. \& Sikora, A., 2018. Lignite biodegradation under conditions of acidic molasses fermentation. International Journal of Coal Geology 196, 274-287.

Dubiński, J. \& Turek, M., 2016. Mining problems of underground coal gasification - reflections based on experience gained in experiment conducted in KHW S.A. Wieczorek Coal Mine. Mining Science 23, 7-20.

EURACOAL, 2018. Euracoal Annual Report 2017. European Association for Coal and Lignite. Brussels, Belgium, https:/ / euracoal.eu/library/annual-reports/

Gotowała, R. \& Hałuszczak, A., 2002. The Late Alpine structural development of the Kleszczów Graben (Central Poland) as a result of a reactivation of the pre-existing, regional dislocation. European Geoscience Union, Stephan Mueller Special Publication Series 1, 137-150.

Hajdo, S., Klich, J., Galiniak, G., Polak, K. \& Różkowski, K., 2012. Criteria of verification of potential lignite resource base for underground gasification. AGH Journal of Mining and Geoengineering 36, 143-150.

Iciek, J., Ziemiński, K., Zawadzka, A. \& Kowalska, M., 2009. Alternatywne metody pozyskiwania energii $z$ węgla brunatnego (in Polish). Górnictwo i Geoinżynieria $33,151-157$.

Kapusta, K. \& Stańczyk, K., 2011. Pollution of water during underground coal gasification of hard coal and lignite. Fuel 90, 1927-1934.

Kapusta, K., Stańczyk, K., Korczak, K., Pankiewicz, M. \& Wiatrowski, M., 2010. Some aspects of impact of underground coal gasification proces on water. Prace Naukowe GIG, Research Reports Mining and Environment 4, 17-26.

Kasiński, J.R., 2010. Resource lignite potential in Poland and its usability. Biuletyn Państwowego Instytutu Geologicznego 439, 87-98.

Kasiński, J.R., 2015. The karst phenomena in the Mesozoic basement of the Ztoczew lignite deposits against structures 
of the Poznań-Kalisz fault zone. [In:] M. Pańczyk (Ed.): Mineral deposits: the prospection, exploration, documentation. Polish Geological Institute, Warsaw, pp. 31-32.

Kasiński, J.R. \& Piwocki, M., 2002. Low rank coals in Poland: prospection, mining, progress. Polish Geological Institute Special Papers 7, 18-30.

Kasiński, J.R. \& Słodkowska, B., 2016. Factors controlling Cenozoic anthracogenesis in the Polish Lowlands. Geological Quarterly 60, 959-974.

Kasiński, J.R., Matl, K. \& Stachowiak, A., 2012. Usefulness $\mathrm{o}$ in Poland for underground coal gasification (UCG) the problem of criteria of economic viability. Biuletyn Państwowego Instytutu Geologicznego 448, 169-182.

Kasiński, J.R., Mazurek, S. \& Piwocki, M., 2006. Valorization and ranking, list of lignite deposits in Poland. Prace Państwowego Instytutu Geologicznego 187, 1-79.

Kasiński, J.R., Piwocki, M., Swadowska, E. \& Ziembińska-Tworzydło, M., 2010. Charakterystyka węgla brunatnego z miocenu Niżu Polskiego na podstawie wybranych profile [Lignite of the Polish Lowlands Miocene: characteristics on the base of selected profiles]. Biuletyn Państwowego Instytutu Geologicznego 439, 99-154.

Kasztelewicz, Z., 2014. Doktryna energetyczna Polski na I połowę XXI wieku [Polish energy doctrine for the first half of the 21st Century]. Polityka Energetyczna - Energy Policy Journal 17, 67-82.

Kasztelewicz, Z., Ptak, M. \& Sikora, M., 2018. Brown coal as an optimal energy raw material for Poland. Zeszyty Naukowe Instytutu Gospodarki Surowcami Mineralnymi i Energia Polskiej Akademii Nauk 106, 61-84.

Kasztelewicz, Z., Zajączkowski, M. \& Sikora, M., 2013. Prospects for open-cast mining and gasification technology implementation in the field of brown coal deposits utilization in Poland. Przeglad Górniczy 69, 139-147.

Klimenko, A.Y., 2009. Early ideas in underground coal gasification and their evolution. Energies 2, 456-476.

Mao, F., 2016. Underground coal gasification (UCG): A new trend of supply-side economics of fossil fuels. Natural Gas Industry B, 3, 312-322.

Matl, K., Kasztelewicz, Z., Kasiński, J., Bielowicz, B. \& Galiniak, G., 2014. Diversification of lignite resource base in Poland for the production of gas using both surface and underground gasification. Przegląd Górniczy 11, 38-46.

Memon, A.A., Shaikh, S.A., Mahar, H., Uqaili, M., Hussain, S., Ashraf, T. \& Palari, A., 2016. Underground coal gasification and utilization of syngas in various fields: a review. Journal of Faculty of Engineering $\mathcal{E}$ Technology 23, 75-85.

Nowak, J. \& Barańska-Buslik, A., 2011. Wstępne typowanie pokładów węgla brunatnego rejonu LGOM do zagospodarowania metodami innowacyjnymi poprzez ich podziemne zgazowanie [Initial selection of lignite deposits from LGOM region for development by innovative underground gasification methods]. Zeszyty Naukowe Instytutu Gospodarki Surowcami Mineralnymi i Energia Polskiej Akademii Nauk 81, 177-195.
Pietraszewski, A., 2018. Polskie górnictwo węgla brunatnego w 2017 roku [Polish lignite mining industry in 2017]. Wegiel Brunatny 102, 4-14.

Piwocki, M. \& Ziembińska-Tworzydło, M., 1997. Neogene of the Polish Lowlands - lithostratigraphy and pollen-spore zones. Geological Quarterly 41, 21-40.

Przybyłek, J. \& Dąbrowski, S., 2017. Planowana kopalnia odkrywkowa na złożu węgla brunatnego „Oczkowice" zagrożeniem dla gospodarki wodnej i środowiska południowo-zachodniej Wielkopolski [The planned "Oczkowice" opencast brown coal mine as a threat to the environment and water management of the south-western Wielkopolska region]. Przeglad Geologiczny 65, 1000-1008.

Ritter, D., Vinson, D., Barnhart, E., Akob, D.M., Fields, M.W., Cunningham, A.B., Orem, W. \& McIntosh, J.C., 2015. Enhanced microbial coalbed methane generation: a review of research, commercial activity, and remaining challenges. International Journal of Coal Geology 146, 28-41.

Sawicki, J., 2010. Hydrogeologiczne i górnicze uwarunkowania eksploatacji złoża węgla brunatnego "Złoczew" [Hydrogeological conditions and mining operation brown coal deposits "Złoczew"]. Prace Naukowe Instytutu Górnictwa Politechniki Wrocławskiej 123, 127-148.

Self, S.J., Reddy, B.V. \& Rosen, M.A., 2012. Review of underground coal gasification technologies and carbon capture. International Journal of Energy and Environmental Engineering 3, 16.

Sobczyk, E.J., Wota, A., Kopacz, M. \& Fraczek, J., 2017. Clean Coal Technologies - a chance for Poland's energy security. Decision-making using AHP with benefits, opportunities, costs and risk analysis. Gospodarka Surowcami Mineralnymi - Mineral Resources Management 33, 27-48.

Stańczyk, K., Howaniec, N., Smoliński, A., Świadrowski, J., Kapusta, K., Wiatowski, M., Grabowski, J. \& Rogut, J., 2011. Gasification of lignite and hard coal with air and oxygen enriched air in a pilot scale ex situ reactor for underground gasification. Fuel 90, 1953-1962.

Szafranek-Nakonieczna, A., Zheng, Y., Słowakiewicz, M., Pytlak, A., Polakowski, C., Kubaczyński, A., Bieganowski, A., Banach, A., Wolińska, A. \& Stępniewska, Z., 2018. Methanogenic potential of lignites in Poland. International Journal of Coal Geology 196, 201-210.

Tajduś, A., Kaczorowski, J., Kasztelewicz, Z., Czaja, P., Cała , M., Bryja, Z. \& Żuk, S., 2014. Brown coal - an offer for Polish power industry - development possibilities for brown coal mining functioning in Poland by the year 2050. Komitet Górnictwa PAN, Kraków, 85 pp.

Uberman, R. \& Naworyta, W., 2012. Eksploatacja złóż węgla brunatnego w warunkach ograniczeń przestrzennych i ekologicznych, studium przypadku złoże Gubin [Lignite exploitation under spatial and environmental restrictions - case study: Gubin lignite deposit]. Polityka Energetyczna-Energy Policy Journal 15, 29-41.

Urbański, P. \& Saternus, A., 2017. Charakterystyka złoża węgla brunatnego Złoczew w aspekcie alternatywnych metod jego wykorzystania [Characteristics of 
Złoczew lignite deposits in the light of alternative methods of use]. Górnictwo Odkrywkowe 58, 71-76.

Urbański, P. \& Widera, M., 2016. Geologia złóż węgla brunatnego w południowo-zachodniej Wielkopolsce [Geology of lignite deposits in the south-western Wielkopolska region]. Przeglad Geologiczny 64, 791798.

WCA, 2018. World Coal Association. https://www. worldcoal.org/coal

Widera, M., 2007. Litostratygrafia i paleotektonika kenozoiku podplejstoceńskiego Wielkopolski [Lithostratigraphy and palaeotectonics of the sub-Pleistocene Cenozoic of
Wielkopolska]. Adam Mickiewicz University Press, Poznań, 224 pp.

Widera, M., 2016. Genetic classification of Polish lignite deposits: A review. International Journal of Coal Geology 158, 107-118.

Widera, M., Kasztelewicz, Z. \& Ptak, M., 2016. Lignite mining and electricity generation in Poland: The current state and future prospects. Energy Policy 92, 151-157.

Manuscript received: 24 February 2020 Revision accepted: 5 May 2020 